\title{
PASSAGES
}

\section{Oliverio O. Segura, MD (1933-2021) Through A Son's Eyes - A Tribute to Dad}

\author{
Peter Paul R. Segura, MD
}

I was born and raised in the old mining town of Barrio DAS (Don Andres Soriano), Lutopan, Toledo City where Atlas Consolidated Mining and Development Corp. (ACMDC) is situated. Dad started his practice in the company's hospital as an EENT specialist in the early 60's and was the 'go to' EENT Doc not only of nearby towns or cities (including Cebu City) but also the surrounding provinces in the early 70's. In my elementary years, he was Assistant Director of ACMDC Hospital (we lived just behind in company housing, only a 3-minute walk). I grew interested in what my dad did, sometimes staying in his clinic an hour or so after school, amazed at how efficiently he handled his patients who always felt so satisfied seeing him. At the end of the day, there was always 'buyot' (basket) of vegetables, live chickens, freshwater crabs, crayfish, catfish or tilapia. I wondered if he went marketing earlier, but knew he was too busy for that (and mom did that) until I noticed endless lines of patients outside and remembered when he would say: "Being a doctor here - you'll never go hungry!" I later realized they were PFs (professional fees) of his patients. As a company doctor, Dad received a fixed salary, free housing, utilities, gasoline, schooling for kids and a company car. It was the perfect life! The company even sponsored his further training in Johns-Hopkins, Baltimore, USA.

A family man, he loved us so much and was a bit of a joker too, especially at mealtimes. Dad's daily routine was from $8 \mathrm{am}-5 \mathrm{pm}$ and changed into his tennis, pelota, or badminton outfit. He was the athlete, winning trophies and medals in local sports matches.

Dad wanted me to go to the University of the Philippines (UP) High School in the city. I thought a change of environment would be interesting, but I would miss my friends. Anyway, I complied and there I started to understand that my dad was not just an EENT practicing in the Mines but was teaching in Cebu Institute of Medicine and Cebu Doctors College of Medicine (CDCM) and was a consultant in most of the hospitals in Cebu City. And still he went back up to the mountains, back to Lutopan, our mining town where our home was. The old ACMDC hospital was replaced with a new state-of-the-art hospital now named ACMDC Medical Center, complete with Burn Unit, Trauma center and an observation deck in the OR for teaching interns from CDCM. Dad enjoyed teaching them. Most of them are consultants today who are so fond of my dad that they always send their regards when they see me.

My dad loved making model airplanes, vehicles, etc. and I realized I had that skill when I was 8 years old and I made my first airplane model. He used to build them out of Balsa wood which is so skillful. I can't be half the man he was but I realized this hobby enhanced his surgical skills. My dad was so diplomatic and just said to get an engineering course before you become a pilot (most of dads brothers are engineers). I actually gave engineering a go, but after $1 \frac{1}{2} 2$ years I realized I was not cut out for it. I actually loved Biology and anything dealing with life and with all the exposure to my dad's clinic and hospital activities ... med school it was!

At this point, my dad was already President of the ORL Central Visayas Chapter and was head of ENT Products and Hearing Center. As a graduate of the UP College of Medicine who finished Otorhinolaryngology residency with an additional year in Ophthalmology as one of the last EENTs to finish in UP-
PGH in the late 50 's, he hinted that if I finished my medical schooling in CDCM that I consider Otorhinolaryngology as a residency program and that UP-PGH would be a good training center. I ended up inheriting the ORL practice of my dad mostly, who taught me some of Ophthalmology outpatient procedures. Dad showed me clinical and surgical techniques in ENT management especially how to deal with patients beyond being a doctor! You don't learn this in books but from experience. I learned a lot from my dad. Just so lucky I guess! He actually designed and made his own ENT Treatment Unit, which I'm still using to this day (with some modifications of my own). And he created a certain electrically powered 'eye magnet' with the help of my cousin (who's an engineer now in Chicago) which can attract metallic foreign bodies from within the eyeball to the surface so they can easily be picked out - it really works!

Dad loved to travel in his younger years especially abroad for conventions or just simply leisure or vacations, most of the time with my mom. But as he was getting older, travels became uncomfortable. His last travel with me was in 2012 for the AAO-HNS Convention in Washington DC. It was a great time as we then proceeded to a US Navy Airshow in nearby Virginia after the convention, meeting up with my brother who is retired from the USN. Then we took the train to New York and stayed with my sister who is a PICU nurse in NY Presbyterian. Then off to Missouri and Ohio visiting the National Museum of the US Air Force, the largest military aircraft museum in the world.

For years, Dad had been battling with heredofamilial-hypercholesterolemia problem which took its toll on his liver and made him weak and tired but still he practiced and continued teaching and sharing his knowledge until he retired at the age of 80 . By then, my wife and I would take him and my mom out on weekends, he loved to be driven around and eat in different places. I really witnessed and have seen how he suffered from his illness in his final years. But he never showed it or complained, never even wanted to use a cane! He didn't want to be a burden to anyone. What most affected me was that my dad passed and I wasn't even there. I had helped call for a physician to rush to the house and had oxygen cylinders to be brought for him as his end stage liver cirrhosis was causing cardio-pulmonary complications (non-COVID). Amidst all this I was the one admitted for 14 days because of COVID-19 pneumonia. My dad passed away peacefully at home as I was being discharged from the hospital. He was 88 . I never reached him just to say good bye and cried when I reached home still dyspneic recovering from the viral pneumonia. I realized from my loved ones who told me that dad didn't want me to stress out taking care of him, as I've been doing ever since, but instead to rest and recuperate myself. I cried again with that thought. In my view, he was not only a great Physician and Surgeon but also the greatest Dad. He lived a full life and touched so many lives with his treatments, charity services and teaching new physicians. It's seeing, remembering and carrying on what he showed and taught us that really makes us miss him. I really love and miss my dad and with a smile on my face, I see he's also happy to be with his brothers and sisters who passed on ahead. And that he's rested. He is a man content, I remember he always said this, ' As long as I have a roof over my head and a bed to rest my back, I'm okay!" 